О.В. Кіико,

канд. техн. наук Г.М. Сіконенко

\title{
УДОСКОНАЛЕННЯ ПЕРЕВЕЗЕННЯ ПАСАЖИРІВ ПРИ РОЗВИТКУ ЗАЛІЗНИЧНОГО ШВИДКІСНОГО РУХУ
}

\author{
Представив д-р техн. наук, професор О.М. Огар
}

Підвищення швидкості руху поїздів одне 3 найважливіших на сьогоднішній день завдань вдосконалення експлуатаційної роботи і розвитку залізничного транспорту в усіх індустріально розвинених країнах світу. Тенденції до збільшення мобільності населення, усвідомлення негативних наслідків нестримної автомобілізації, особливо в екологічному відношенні, необхідність економії енергетичних ресурсів нафтового походження - ці та інші фактори визначають необхідність розвитку швидкісних і високошвидкісних пасажирських перевезень рейковим транспортом. Розвиток сприяє розширенню зон тяжіння великих міст, зниженню транспортних подій, шкідливого впливу на навколишнє середовище; прискорює науково-технічний прогрес на залізничному транспорті, в транспортному будівництві i транспортному машинобудуванні: підвищує конкурентоспроможність залізничного транспорту.

На меті також $є$ розвиток супутніх послуг, які може надавати залізниця, наприклад, розвиток залізничного туризму. Невід'ємною частиною прогресивних залізниць $\epsilon$ широкий спектр інформаційних i інтерактивних послуг на вокзалах і через мережу Інтернет. Вирішальним кроком у забезпеченні конкурентоспроможності та стійкого розвитку пасажирських 
залізничних перевезень має стати робота зі створення конкурентного ринку транспортних послуг із застосуванням системи фірмового транспортного обслуговування. Експлуатаційна робота залізниць має повністю задовольняти потреби населення, при цьому використання технічних засобів має бути ефективним, що несе за собою системне зниження собівартості перевезень.

Одним 3 найперших напрямів підвищення якості пасажирських перевезень $є$ запровадження швидкісного руху. Однак при цьому необхідно вирішити проблему розподілу мережі на лінії 3 переважно вантажним i переважно пасажирським рухом та підвищити частоту руху пасажирських поїздів.

Великий внесок у розвиток економічної теорії та питань вдосконалення перевезень пасажирів на залізничному транспорті зробили такі вчені: А.П. Абрамов, М.М. Барков, І.В. Бєлов, А.В. Болотін, Т.В. Бутько, Б.А. Волков, А.Є. Гибшман, В.Г. Галабурда, М.І. Данько, Ю.В. Дьяков, Т.М. Муджирі, Є.А. Сотников, В.Г. Савельєв, В.М. Саввов, Б.І. Шафіркін, Ш.М. Шайдуллін, П.О. Яновський та ін.

Чіткого визначення високошвидкісного залізничного транспорту поки що не існує. До такого виду транспорту прийнято відносити такий тип залізничного транспорту, який пересувається значно швидше, ніж звичайний поїзд. Зазвичай високошвидкісний транспорт рухається зі швидкістю понад 200 км/год.

Швидкість найсучасніших поїздів не перевищує 350 км/год, на більш високих швидкостях виникають різні фізичні та електричні проблеми. Можливо, в майбутньому з'явиться супершвидкісний транспорт зі швидкістю більше 350 км/год [1].

Один 3 аспектів високошвидкісного транспорту - спеціальна рейкова колія 3 дуже великим радіусом повороту, рейки повинні бути зварені разом і мати хорошу основу, щоб уникнути коливань i пошкоджень. Рейки повинні бути без стиків i без однорівневих переїздів для автомобілів. В основному, для такого транспорту використовують електровози.

Загальна протяжність високошвидкісних магістралей (ВШМ) у світі в даний час складає без малого 7000 км, у тому числі 3750 км в Європі, причому високошвидкісні поїзди обслуговують також полігон протяжністю близько 20 тис.км звичайних залізничних ліній, реконструйованих під швидкісний рух.

Швидкісні залізниці, які поширені в економічно розвинених країнах світу, мають важливе соціально - економічне значення для задоволення транспортних потреб i підвищення якості життя населення. Високошвидкісні залізниці $\epsilon$ «потужним локомотивом» прогресу для всієї залізничної галузі тієї чи іншої країни і навіть континенту в цілому.

У число країн, які найбільш активно здійснюють проекти організації швидкісного i високошвидкісного руху, входять Японія, Франція, Німеччина, Італія, Іспанія.

Зарубіжний досвід говорить про значну соціально-економічну ефективність використання швидкісного високошвидкісного руху:

- забезпечується набагато більш високий рівень обслуговування пасажирів за рахунок скорочення часу перебування пасажира на шляху прямування, за швидкістю пересування реально конкуруючи з авіатранспортом;

- підвищується безпека руху, знижується рівень травматизму на залізничному транспорті;

- досягається значний екологічний ефект, при цьому сучасні будівельні технології дозволяють звести до мінімуму шкоду при прокладанні нових залізничних ліній;

- підвищується рівень зайнятості населення завдяки зростанню його мобільності;

- прискорюється технічна i технологічна модернізація підприємств 
транспортного машинобудування i транспортного будівництва.

Останнім часом набули розповсюдження, в тому числі і на Україні, поїзди категорії Інтерсіті та Інтерсіті+. InterCity (ІнтерСіті) - це клас швидкісних міжміських поїздів у ряді європейських країн, відмітною особливістю яких $є$ те, що вони роблять проміжні зупинки на шляху прямування тільки у великих містах країни або на вузлових станціях. Саме це відрізняє поїзди класу ІнтерСіті від приміських i пасажирських поїздів [2].

Назва ІнтерСіті закріпилася за класом таких поїздів за аналогією з однойменним денним поїздом, який ввели у Великобританії за маршрутом Лондон Бірмінгем в 1950 р. Це був фірмовий поїзд «InterCity», i caме назва цього поїзда вважається оригінальною, а всі наступні назви аналогічних поїздів класу Інтерсіті по всьому світу є запозиченими.

У 1966 p. Британська залізнична компанія прийняла бренд InterCity для всіх своїх поїздів експрес-класу на всіх внутрішніх маршрутах, а в 1986 р. цей термін був наслідуваний сектором експреспоїздів ІнтерСіті британської залізниці. У результаті приватизації залізниці у Великобританії термін «ІнтерСіті» більше не вживається офіційно, але більшість людей, як i раніше, називають так швидкісні поїзди далекого прямування.

Зараз поїзди класу ІнтерСіті курсують в більшості великих країн - так, на сьогодні ці поїзди перевозять пасажирів в 22 країнах Європи.

В Україні поїзди ІнтерСіті i ІнтерСіті+ з'явилися завдяки підготовці країни до чемпіонату СВРО-2012, незважаючи на те, що українська залізниця планувала впровадження швидкісних поїздів такого класу ще на початку минулого десятиліття. Так, однією зі спроб став поїзд «Столичний експрес», що поєднав Київ 3 Харковом і 3 Дніпропетровськом, а пізніше і зі Львовом. Час в дорозі становив 5-7 годин, що на той момент було відмінною економією часу для пасажирів. Українська залізниця прийняла рішення ввести швидкісні міжміські поїзди і для інших напрямків, однак до 2006 р. цей напрямок розвивався дуже повільно. У 2007 р., коли стало відомо, що Україна прийме матчі ЄВРО-2012, розвиток швидкісного руху поїздів було включено в стратегічний план підготовки до чемпіонату.

На початку грудня 2010 p. був підписаний договір про постачання в Україну швидкісних поїздів Hyundai, а на початку грудня 2011 р. вже відбулася передача першого поїзда Hyundai українській стороні. Поїзди класу ІнтерСіті і ІнтерСіті+ почали свій рух по залізницях України 7 червня 2012 p. Порівняльну характеристику часу знаходження поїздів між основними напрямками Укрзалізниці наведено у таблиці.

При розвитку швидкісного руху на залізницях України необхідним є технікоекономічне обгрунтування проектів швидкісних магістралей. Слід виходити 3 того, що ефект, отриманий в інших галузях i сферах суспільства від організації швидкісного руху, багаторазово перевершує галузеву вигоду самого транспорту.

Таким чином, при виборі варіантів організації швидкісного руху поїздів потрібно враховувати не тільки інтереси транспорту (перевізника), а й інтереси пасажира як споживача дорожчої послуги; переходячи в розрахунках від поняття вартості до поняття корисності [3]. Це означає, що виникає проблема оцінки самим пасажиром цінності своєї пассажиро-години або кількісної оцінки закону економії часу.

Немає сумніву в тому, що проблема підвищення швидкості руху пасажирських поїздів в Україні повинна стати одним 3 найважливіших аспектів соціальної політики держави, а транспортні проекти та програми у сфері пасажирських перевезень повинні сприйматися не як комерційні підприємства, а як проекти макроекономічного рівня. 
Таблиця

Порівняльна характеристика часу руху поїздів різних категорій

\begin{tabular}{|c|c|c|c|c|c|}
\hline \multirow[b]{2}{*}{ Маршрут } & \multirow{2}{*}{$\begin{array}{l}\text { Номер } \\
\text { поїзда }\end{array}$} & \multirow[b]{2}{*}{ Категорія } & \multicolumn{3}{|c|}{ Чac } \\
\hline & & & відправлення & прибуття & $\begin{array}{c}\text { на шляху } \\
\text { прямування }\end{array}$ \\
\hline $\begin{array}{c}\text { Харків - } \\
\text { Київ }\end{array}$ & $\begin{array}{c}063 \mathrm{O} \\
\text { «Оберег» }\end{array}$ & $\begin{array}{c}\text { Нічний } \\
\text { швидкий }\end{array}$ & $22: 20$ & 07:08 & 8 год 48 хв \\
\hline $\begin{array}{c}\text { Харків - } \\
\text { Київ }\end{array}$ & $\begin{array}{c}1610 \\
\text { «Столичний } \\
\text { експрес» }\end{array}$ & Інтерсіті + & $06: 56$ & $11: 37$ & 4 год 41 хв \\
\hline $\begin{array}{c}\text { Донецьк - } \\
\text { Київ }\end{array}$ & $\begin{array}{c}\text { 037Д } \\
\text { «Донбас» }\end{array}$ & $\begin{array}{c}\text { Нічний } \\
\text { швидкий }\end{array}$ & $19: 41$ & $07: 41$ & 12 год \\
\hline $\begin{array}{c}\text { Донецьк - } \\
\text { Київ }\end{array}$ & 152Д & Інтерсіті + & $06: 28$ & $13: 20$ & 6 год 52 хв \\
\hline Одеса - Київ & $010 \mathrm{~K}$ & $\begin{array}{c}\text { Нічний } \\
\text { швидкий }\end{array}$ & $00: 52$ & $09: 24$ & 8 год 32 хв \\
\hline Київ - Львів & $169 \mathrm{~K}$ & Інтерсіті + & 17.11 & 23.25 & 6 год 14 хв \\
\hline Київ - Львів & $\begin{array}{c}092 Л \\
\text { «Львів» }\end{array}$ & $\begin{array}{c}\text { Нічний } \\
\text { швидкий }\end{array}$ & $22: 53$ & $06: 40$ & 7 год 47 хв \\
\hline
\end{tabular}

Однак на сьогоднішній день головною метою $\epsilon$ створення умов для підвищення мобільності населення , розвитку міжрегіональних економічних і культурних зв'язків на основі реалізації програми розвитку високошвидкісного і швидкісного сполучення в Україні, в першу чергу між найбільшими центрами країни , що дозволяє скоротити час знаходження у дорозі, зробити Україну зручною для туризму, розвантажити автомобільні дороги в міжміському i приміському сполученні. Створити для пасажирів більш привабливі умови, підвищити комфортність i безпеку пасажирських перевезень , забезпечити зручний час відправлення i прибуття пасажирів.
Висновок. Створення привабливих умов транспортного забезпечення в умовах розвитку швидкісного руху дозволить залучити на залізничний транспорт додатковий пасажиропотік $з$ авіаційного та автомобільного транспорту, а також скоротити збитковість пасажирських перевезень на цих напрямках. Крім того, організація швидкісного

високошвидкісного руху забезпечує підтримання та подальше стимулювання науково-технічного та інтелектуального потенціалу країни за рахунок розміщення на вітчизняних підприємствах замовлень на створення нових зразків техніки світового рівня.

\section{Список літератури}

1. Элин, В.В. Скоростные железнодорожные линии в Западной Европе [Электронный pecypc]. - Режим доступа: http://commi.narod.ru/txt/1990/0317.htm - загл. с экрана.

2. Понятие «Инетрсити». Начало курсирования [Электронный ресурс]. - Режим доступа: http://intercity.kiev.ua/o-poezdah-intercity.- загл. с экрана.

3. Васюнина, А.А. Экономическая эффективность реконструкции железнодорожных линий для организации скоростного пассажирского движения [Текст]: дис. ... канд. техн. наук / А.А. Васютина. - М., 2008. - 204 с. 
Ключові слова: залізничний швидкісний рух, пасажиропотік, якість пасажирських перевезень.

\section{Анотації}

Одним із напрямків підвищення конкурентоспроможності залізниць та стійкого розвитку залізничних пасажирських перевезень є подальший розвиток швидкісного руху. Максимальний ефект при цьому досягається при відокремленні пасажирського й вантажного pyxy.

При техніко-економічному обгрунтуванні доцільності функціонування швидкісних поїздів на залізницях України необхідно мати на увазі не тільки галузевий ефект (інтереси перевізника), а й кількісну оцінку закону економії часу.

Одним из направлений повышения конкурентоспособности железных дорог и устойчивого развития железнодорожных пассажирских перевозок является дальнейшее развитие скоростного движения. Максимальный эффект при этом достигается при разделении пассажирского и грузового движения.

При технико-экономическом обосновании целесообразности функционирования скоростных поездов на железных дорогах Украины необходимо иметь в виду не только отраслевой эффект (интересы перевозчика), но и количественную оценку закона экономии времени.

One of the ways of increasing the competitiveness of railways and the sustainable development of rail passenger services is the further development of high-speed movement. The maximum effects are achieved by the separation of passenger and freight movement.

If the feasibility study of the feasibility of high-speed operation of trains on the railways of Ukraine should keep in mind not only the sectoral effect (the interests of the carrier) but also quantify the law of economy of time. 